ORIGINAL ARTILE

AFRICAN JOURNAL OF CLINICAL AND EXPERIMENTAL MICROBIOLOGY ISBN 1595-689X ＳEPTEMBER 2018

AJCEM/1836 http://www.ajol.info/journals/ajcem

COPYRIGHT 2018 https://dx.doi.org/10.4314/ajcem.v19i4.4

AFR. J. CLN. EXPER. MICROBIO. 19 (4):268 -273

\title{
THE PREVALENCE OF NON-TUBERCULOUS RECURRENT COUGH IN-PATIENTS WITHIN CROSS RIVER STATE, NIGERIA
}

${ }^{1}$ Akpan, M. M. and ${ }^{1,2^{*}}$ Adegoke, A. A.

${ }^{1}$ Department of Microbiology, University of Uyo, Uyo, Akwa Ibom State, Nigeria;

${ }^{2}$ Department of Biochemistry and Microbiology, University of Fort Hare, Alice 5700, South Africa.

*Correspondences: Anthony Ayodeji ADEGOKE (Ph.D), aadegoke@ufh.ac.za

\begin{abstract}
Introduction: Nontuberculous recurrent cough is becoming rampant among hospitalized patients.
\end{abstract}

Aim: Hospitalized patients and out-patients in some hospitals in Cross River State were studied for the prevalence of nontuberculous recurrent cough in the state

Methods: This was carried out using standard procedures in Microbiology.

Results: The bacterial isolates from the sputum samples were Staphylococcus aureus, Streptococcus pneumoniae, Streptococcus pyogenes, Haemophilus influenzae, Escherichia coli, Klebsiella pneumoniae, and Corynebacterium diphtheriae. The patients' age group 20 - 39 years had the highest prevalence of non - tuberculous recurrent cough $(46.7 \%)$ while the least prevalence of $1.0 \%$ was among the age group $\geq 80$ years. The prevalence rate of $33.7 \%$ was the highest among the social class and businessmen, while the least prevalence rate of $8.2 \%$ was found among students. Out of a total of 1466 samples studied, $93.6 \%$ was nontuberculous cases.

Conclusion: Mycobacterium tuberculosis is therefore not the predominant cause of cough in the study area as at the time of this study

Keywords: non-tuberculosis, recurrent cough, Ziehl-Neelsen, Mycobacterium tuberculosis

\section{LA PRÉVALENCE DE LA TOUX RÉCURRENTE NON À DES PATIENTS AU SEIN DE L'ÉTAT DE CROSS RIVER, AU NIGÉRIA}

${ }^{1}$ Akpan, M. M. and ${ }^{1,2^{*}}$ Adegoke, A. A.

1Département de microbiologie de l'Université d'Uyo, Uyo, Akwa Ibom State, Nigeria ; 2Département de biochimie et microbiologie de l'Université de Fort Hare, Alice 5700, Afrique du Sud.

*Correspondances : Anthony Ayodeji ADEGOKE (Ph.D), aadegoke@ufh.ac.za

RÉSUMÉ

Introduction: La toux récurrente non devient monnaie courante chez les patients hospitalisés. Objectif : les patients hospitalisés et les patients externes dans certains hôpitaux dans l'État de Cross River ont été étudiés pour la prévalence de la toux récurrente non tuberculeuse dans l'état

Méthodes: Il a été réalisé à l'aide de procédures standard en microbiologie.

Résultats: Les isolats bactériens de l'échantillons d'expectoration étaient Staphylococcus aureus, Streptococcus pneumoniae, Streptococcus pyogenes, Haemophilus influenzae, Escherichia coli, Klebsiella pneumoniae, et de Corynebacterium diphtheriae. Le patients' le groupe d'âge 20 - 39 ans ont la plus forte prévalence de non - toux récurrentes tuberculeuse $(46,7 \%)$ tandis que la prévalence de moins de $1,0 \%$ a été parmi le groupe d'âge de moins de 80 ans. . Copyright (C2017 AJCEM. This work is licensed under the Creative Commons Attribution 4.0 International License CC-BY 
Le taux de prévalence de $33,7 \%$ a été le plus élevé parmi les classes sociales et d'affaires, alors que les taux de prévalence de $8,2 \%$ a été constaté chez les élèves. Sur un total de 1466 échantillons étudiés, 93,6 \% des cas non tuberculeuse -.

Conclusion: Mycobacterium tuberculosis n'est donc pas la principale cause de la toux dans la zone d'étude au moment de l'étude

Mots clés: non-tuberculose, toux récurrentes, Mycobacterium tuberculosis, Ziehl-Neelsen

\section{INTRODUCTION}

Some reflex actions are evidence that pathogens or pollen had gained entrance into the body and such action (s) is/are meant to eliminate the non-self component and excessive mucus. Cough is an example of such sudden mechanical action. It is controlled by same contraction of muscles that control breathing $[1,2]$ and it expels deoxygenated contaminated air from the lungs. Coughing, a reflex response of the body caused by an irritation in the throat or windpipe, participate in protecting the delicate lung tissue from pathogens and other substances [2-4]. Apart from the need to eliminate infections, other causes of cough include allergies and cancer.

Cough can be acute, sub-acute or chronic ${ }^{5}$. Acute cough lasts for a short period of time not exceeding 21days. It is usually due to viral infection or bacterial infection of the upper respiratory tract infections (URTI) among others [2]. As soon as the infection being cleared is eliminated, acute cough seizes. So, it is usually transient. Chronic cough may be caused by a variety of underlying diseases including asthma, cystic fibrosis, allergies, gastroesophageal reflux disease (GERD), and chronic postnasal drip [6,7]. A cough may be productive or dry. A productive cough brings up mucus while a dry cough does not. Dry cough may result from a viral illness and may last up to several weeks. Children with pneumonia can appear sick with fever and a mild cough or be very ill with high fever and laboured breathing [8]. Pneumonia is caused either by viruses or bacteria. For proper diagnosis of cough, information regarding the duration of cough, other symptoms that may accompany it and the environmental factors that may influence it are very useful. The treatment of cough, like other symptoms depends highly on the severity and underlying cause of the cough. Acute cough like pneumonia may require antibiotics. Anti-tussives suppress a cough. Cough suppressants may lessen cough while dextromethorphan depresses the brain's cough centre.

Non - tuberculous Mycobacteria (NTM) have emerged as important opportunistic pathogen of the human being in recent years. They are ubiquitous as environmental organisms that sometimes cause respiratory disease usually in patients with preexisting pulmonary damage [9]. Mycobacterial studies have been conducted on the citizens in South Africa [10, 11]. On one of such studies, the sputum from 1,196 Zulus in Natal, South Africa, the presence of mycobacteria was assessed ${ }^{10}$ without recourse to clinical information. A NTM prevalence rates of colonization/infection was 1,400/100,000.

A similar research among patients with lower respiratory infection in Chest Clinic in Lagos, Nigeria showed the screening of six hundred and sixty eight ramdomly for pulmonary tuberculosis [12]. An observation of $11 \%$ NTM prevalence was made.

Information on NTM or non tuberculous recurrent cough in the study location was rare to the best of our knowledge. This study therefore was aimed at assessing the prevalence of non tuberculous recurrent cough in patients with recurrent cough in Cross River State, Nigeria.

\section{MATERIAL AND METHODS Sources and Collection of Samples}

One thousand four hundred and sixty six sputa were collected from both in - patients and out - patients in hospitals with recurrent and productive cough in Cross River State. The study was carried out from January to October 2009 (10 months). Sputum from each patient was collected into a sterile universal bottle in the hospital and transported to the laboratory for analysis within 2 hours of collection. The hospitals studied represent different community/locations. The referral hospitals include Infectious Disease Hospital, Ogoja (IDHO), General Hospital, Ugep (GHU), General Hospital, Calabar (GHC), General Hospital, Obudu (GHB), General Hospital, Ikom, (GHI), General Hospital, Akamkpa (GHA), and General Hospital, Ogoja (GHO). The research was done without violating the ethical standards and the patients' right.

\section{Processing Of Samples for Microscopic Examination}

Ziehl Neelsen staining technique was used to stain each of the sputum samples to isolate samples which contained acid - fast bacilli (AFB) [13-17]. 


\section{Sputum culture and Identification of bacteria}

A sterile wire loop was used to aseptically inoculate each of the sputum samples on Blood agar, MacConkey agar and Chocolate agar for microbial morphology and identification. The seeded plates were then incubated. Blood agar and McConkey agar plates were incubated aerobically at $37^{\circ} \mathrm{C}$ for 24 hours while chocolate agar plates were incubated in a carbon (IV) oxide enriched atmosphere at $37^{\circ} \mathrm{C}$ for 24 hours. All the isolates were purified by sub-culturing. The pure culture of the isolate were characterized and identified using colonial morphology, Gram's staining, microscopic examination, biochemical tests and sugar ferment action profile. Biochemical tests carried out were coagulase, oxidase, catalase, citrate, urease, bile solubility, indole, Voges-Proskauer, methyl red, nitrate reduction, motility, and spore tests [18-20].

Statistical Analysis: The results were statistically analyzed using ANOVA with the $p>0.05$

\section{RESULTS AND DISCUSSION}

Out of the 1466 samples studied, five hundred and forty eight $(37.4 \%)$ samples were collected from Infectious Disease Hospital, Ogoja; 169 (11.2\%) were collected from General Hospital, Calabar, 120 (8.2\%) from General Hospital, Ogoja; 126 (8.6\%) from General Hospital, Ugep; 250 (17.1\%) from General Hospital, Ikom; 189 (12.9\%) from General Hospital, Obudu and $64(4.4 \%)$ of the samples were collected from General Hospital, Akamkpa. 1372 (93.6\%) were AFB-negative while 94 (6.4\%) were AFB positive. The hospital which had the highest no of TB patients was infectious Disease Hospital, Ogoja with the prevalence of 532 (97.1\%) out of 548 tested; followed by General Hospital, Ugep with the rate of 122 $(96.8 \%)$ out of 126 screened, then General Hospital, Calabar 158 (93.5\%) out of 169 screened, General Hospital, Obudu 178 (93.1\%) out of 189 studied, General Hospital, Ogoja 110 (91.7\%) out of 120 sampled, General Hospital, Akamkpa 56 (87.5\%) out of 64 screened, while General Hospital, Ikom had the least prevalence 218 (87.2\%) (Table1). Results of social class prevalence revealed that businessmen were the most affected group with the prevalence of $33.7 \%$, followed by farmers with the rate of $28.5 \%$; public/civil servants had the prevalence of $19.8 \%$ while dependents had $9.9 \%$ prevalence. However, students recorded the least prevalence of $8.2 \%$ (Table 2).

The age prevalence results revealed that adults aged 20 - 39 years had the prevalence of $46.7 \%$ which happened to be the highest. Adults aged 40 - 59 years recorded the prevalence of $25.2 \%$, the age group between 60 - 79 years recorded $11.3 \%$ prevalence while children and adolescents between the age of 0 19 years old had the prevalence $9.5 \%$; adults 80 years old and above recorded the least prevalence of $1.0 \%$ (Table 3). The sex prevalence results revealed that male had the highest prevalence of $93.2 \%$ out of 755 samples studied (i.e 704 positive samples) while female had $94.0 \%$ prevalence of the 668 samples studied (Table 4) (i.e. 628 positive samples). The increase on the male prevalence might be due to active lifestyles leading to exposure to the aetiologies. There was statistical significant difference $(p>0.05)$ in the prevalence among male and female subjects studied. Different bacteria encountered in this research include Staphylococcus aureus, Streptococcus pneumonia, Streptococcus pyogenes, Haemophilus influenzae, Escherichia coli, Klebsiella pneumoniae, Corynebacterium diphtheriae. The adults between the ages of $20-39$ years had the highest prevalence with the rate of $46.7 \%$, This high prevalence may be due to exposure to recreational activities. The highest prevalence of $33.7 \%$ recorded by businessmen in the social class may be as result of exposure to over crowded places during business. The prevalence of $93.6 \%$ in this study is comparatively higher than $6.7 \%$ prevalence of non - tuberculous mycobacteria in bronchiectatic population reported by Guang - Suo et al. [9]. Many researchers have undertaken some studies on detailed analysis of non - tuberculous mycobacteria (NTM). Wickremasinghe et al. [21] reported $2 \%$ of NTM patients in the context of bronchiectasis. Fowler et al. [22] reported $10 \%$ of prevalence of NTM out of 98 patients in a cohort of patients with adult onset of bronchiectasis. The result obtained from this study is in agreement with earlier report by Pasteur et al. [23] who found low prevalence in their studies. Serious emphasis should be laid on non-tuberculous Mycobacteria. 
TABLE 1: DISTRIBUTION OF NON - TUBERCULOUS COUGH AMONG THE HOSPITAL STUDIED

\begin{tabular}{llll}
\hline Hospitals & Total Number of Samples & AFB-Negative & AFB-Positive \\
\hline IDHO & $548(37.4)$ & $532(97.1)$ & $16(2.9)$ \\
GHC & $169(11.5)$ & $158(93.5)$ & $11(6.5)$ \\
GHO & $120(8.2)$ & $110(91.7)$ & $108.3)$ \\
GHO & $126(8.6)$ & $122(96.8)$ & $4(3.2)$ \\
GHI & $250(17.1)$ & $218(87.2)$ & $32(12.8)$ \\
GHB & $189(12.9)$ & $178(93.1)$ & $13(6.9)$ \\
GHA & $64(4.4)$ & $56(87.5)$ & $8(12.5)$ \\
Total & $1466(100)$ & $1372(93.6)$ & $94(6-4)$ \\
\hline
\end{tabular}

TABLE 2: SOCIAL CLASS PREVALENCE OF AFB-NEGATIVE CASES IN CROSS RIVER STATE

\begin{tabular}{|c|c|c|c|c|c|c|}
\hline Location & $\begin{array}{l}\text { Total AFB } \\
\text { Negative cases }\end{array}$ & Students & Business & Farmers & $\begin{array}{l}\text { Public/Civil } \\
\text { servant }\end{array}$ & Dependent \\
\hline IDHO & 532 & 30(5.6) & $116(30.3)$ & $156(29.3)$ & 95(17.9) & 90(16.9) \\
\hline GHC & 158 & $20(12.7)$ & $59(37.3)$ & $16(10.1)$ & $55(34.8)$ & $8(5.1)$ \\
\hline GHO & 110 & $20(18.2)$ & $36(32.7)$ & $28(25.5)$ & $20(18.2)$ & $6(5.5)$ \\
\hline GHI & 218 & 18(8.3) & $79(36.2)$ & $74(33.9)$ & $30(13.8)$ & $17(7.8)$ \\
\hline GHB & 176 & $15(8.5)$ & $71(40.3)$ & $44(25.0)$ & $36(20.5)$ & $10(5.7)$ \\
\hline GHA & 56 & $4(7.1)$ & $10(17.9)$ & $23(41.1)$ & 19(33.9) & $0(0)$ \\
\hline TOTAL & 1372 & $112(8.2)$ & $462(33.7)$ & $391(28.5)$ & 271(19.8) & 136(9.9) \\
\hline
\end{tabular}

TABLE 3: AGE RELATED PREVALENCE OF NON-TUBERCULOSIS COUGH IN CROSS RIVER STATE

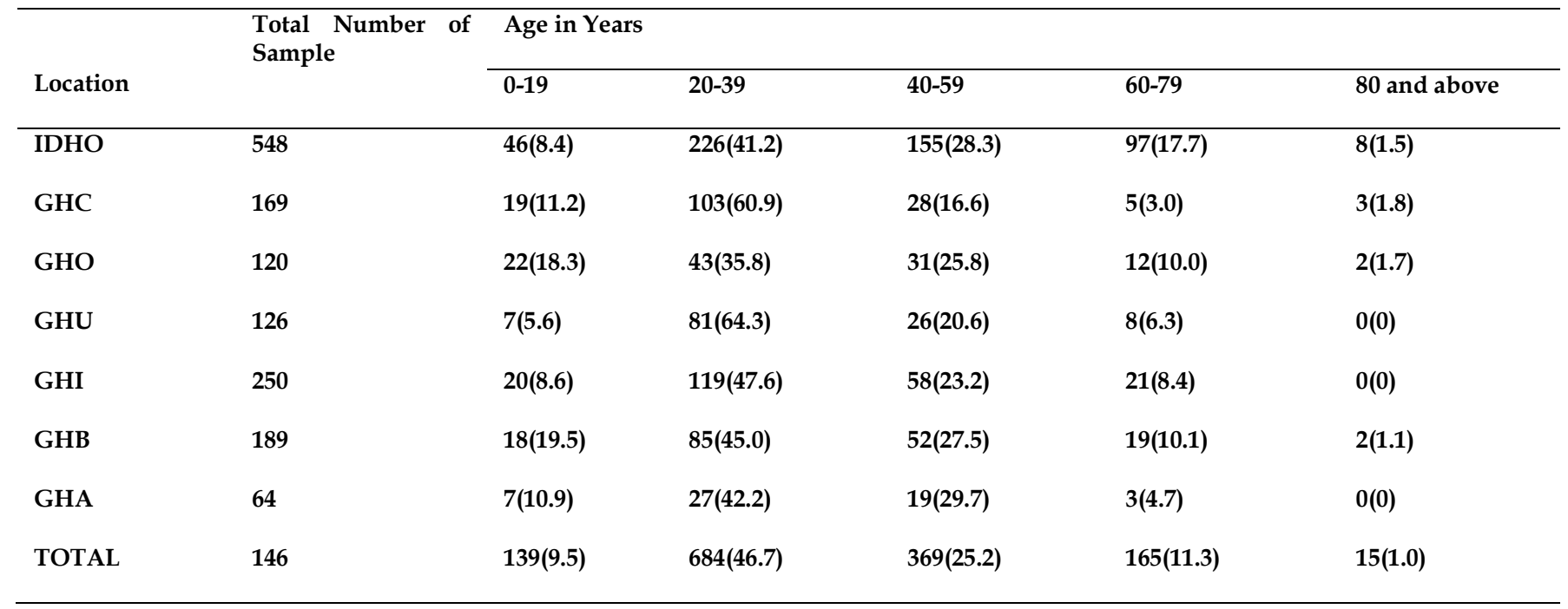


TABLE 4: PREVALENCE OF NON-TUBERCULOSIS RECURRENT COUGH IN CROSS RIVER STATE BASED ON SEX

\begin{tabular}{|c|c|c|c|c|c|}
\hline \multirow[b]{2}{*}{ Hospitals } & \multirow{2}{*}{$\begin{array}{l}\text { Total No. of } \\
\text { Samples }\end{array}$} & \multicolumn{2}{|c|}{ No. of Samples (\%) } & \multicolumn{2}{|c|}{ AFB-Negative Case } \\
\hline & & Male & Female & Male (\%) & Female (\%) \\
\hline IDHO & 548 & $296(54.0)$ & $252(46.0)$ & $287(97.0)$ & $245(97.2)$ \\
\hline GHC & 169 & $72(42.6)$ & 97(57.4) & 65(90.3) & 93(95.9) \\
\hline GHO & 120 & $69(57.5)$ & $51(42.5)$ & $65(94.2)$ & $45(88.2)$ \\
\hline GHU & 126 & $49(38.9)$ & $77(61.1)$ & 46(93.9) & $76(98.7)$ \\
\hline GHI & 250 & $140(56.0)$ & $110(44.0)$ & 123(87.9) & 95(90.9) \\
\hline GHB & 189 & $99(52.4)$ & $90(47.6)$ & 91(91.9) & $85(94.4)$ \\
\hline GHA & 64 & $30(46.9)$ & $34(53.1)$ & $27(90.0)$ & $29(85.3)$ \\
\hline Total & 1466 & $755(51.5)$ & $711(48.5)$ & 704(93.2) & $668(94.0)$ \\
\hline
\end{tabular}

\section{CONCLUSION}

Cough in the study area originated as a reaction from non non - tuberculous infection. The patients' age group $20-39$ years had the highest prevalence of non - tuberculous recurrent cough while the least prevalence was among the age group $\geq 80$ years. The prevalence rate of $33.7 \%$ was the highest among the social class and businessmen, while the least

\section{REFERENCES}

2 Irwin, R. S. Boulet, L. P., Cloutier, M. M. Managing Cough as a Defense mechanism and a Symptom. A Consensus Panel Report of American College of Chest Physician. Chest, 1998; 144 (Suppl (2) 13351815.

3 Willey, J. M., Sherwood, L.M. and Woolverton, C. J. Prescott, Harley and Klein's Microbiology (7th edition). McGraw-Hill companies inc., America, New York, 2008; 761.

3. Eccles R. Acute cough: epidemiology, mechanisms and treatment. Acute and chronic cough. Lung biology in health and disease. Redington A, Morice A (eds) 2005; 205:215-236.

4. Pratter MR: Overview of common causes of chronic cough: ACCP evidence-based clinical practice guidelines. Chest, 2006; 129S:59S-62S. prevalence rate was found among students. There was statistical significant difference $(p>0.05)$ in the prevalence among male and female subjects studied. Non - tuberculous prevalence rate of $93.6 \%$ was observed. Mycobacterium tuberculosis is therefore not the predominant cause of cough in the study area as at the time of this study.

5. De Blasio, F., Virchow, J.C., Polverino, M., Zanasi, A., Behrakis, P.K. Kilinc, G. and Balsamo, R. Cough management: a practical approach. BMC 2011; http://www.coughjournal.com/content/7/ $1 / 7$

6. Irwin R.S. and Madizon, J. M. The Diagnosis and Treatment of Cough. N. Engl J Med. 2000; 343:1715-1721.

7. Ayik SO, Basoglu OK, Erdínç M, Bor S, Veral A, Bílgen C: Eosinophilic bronchitis as a cause of chronic cough. Respir Med 2003, 97:695-701

8. Nester, E. W., Anderson, D. G., Robert C. E., Pearsall, N. N., Nester, M. T. Microbiology: A Human Perspective (4th edition). McGraw-Hill Companies Inc., America, New York. 2004; 20

9. Guang-suo, W., Zheng, W., Lin, Y., Shao-lin, L. and Jin,-Song, W. Thoracoscopic Management for Bronchiectasis with Nontuberculosis Mycobacterial Infection. Chinese Med. J. 2008; 121(24):2539-2543. 
10. Arabin, G., Gartig, D., Kleeberg, H.H. First tuberculosis prevalence survey in KwaZulu. S Afr Med J 1979; 56: 434-438.

11. Fourie, P.B., Gatner, E.M., Glatthaar, E., Kleeberg, H.H. Follow-up tuberculosis prevalence survey of Transkei. Tubercle 1980; 61: 71-79.

12. Idigbe, E.O., Anyiwo, C.E., Onwujekwe, D.I. Human pulmonary infections with bovine and atypical mycobacteria in Lagos, Nigeria. J Trop Med Hyg 1986; 89: 143-148.

13. Baker, F. J. Kilshaw, D. and Silveston, R. E. Preparation of Culture Media. In: Baker, F. J., Kilshaw, D. and Silverton, R. E., (eds). Introduction to Medical Laboratory Technology. Butterworth, London, 1998; 261-264.

14. Cruickshank, R., Duguid, J. P., Swain, R. H. A. Characterization and Identification of isolates. In: Cruickshank, R., Duguid, J. P., Marmoin, B. P. and Swain, R. H. A. (eds). Medical Microbiology, Vol. 11. Longman, London. 1975; 170-190.

15. Harley, J. P. and Prescott, L. M. Laboratory Exercise in Microbiology (3rd edition). WCB. McGraw-Hill, Boston. Companies Inc., Boston, Massachusetts. 1996; 21-31,195-197.

16. Itah, A. Y. and Udofia, S. M. Epidemiology and Endemicity of Pulmonary Tuberculosis (PTB) in Southeastern Nigeria. Southeast Asian J. Trop Med Pub. Health. 2005; 36(2):317-323.
17. Sharma, K. Manual of Microbiology: Tools and Techniques, (2nd edition). Ann Books Gopaljee Enterprises, Dehi, India. 2008; 163$165 ; 181-187$.

18. Cowan, S. T. Cowan and Steel's Manual for Identificationof Medical bacteria (4th $e d$.$) .$ Cambridge University Press, London, pp. $1985 ; 102-126$.

19. Hott, J. G., Kreig, T. N., Sneath, P. H., Stanley, J. T., Williams, S. T. Bergey's Manual of Determinative Bacteriology (9th ed). Williams and Wilkins Publishers, Baltimore. 1994

20. Cheesebrough, M. (2006). District Laboratory Practice in Tropical Countries. (2nd ed.) Part 2. Cambridge University Press. 2006; 39-41.

21. Wickremasinghe, M., Ozerovitch, L. J., Davies, G. (2005). Non-tuberculosis Mycobacteria in Patients with Bronchiectasis. Thorax, 2005; 60:1045-1051.

22. Fowler, S. J., French, J., Screaton, N. J., Foweraker, J., Condliffe, A., Haworth, C. S. Non-tuberculosis Mycobacteria in Bronchiectasis: Prevalence and Patient characteristics. Eur Respir J., 2006; 28: 12041210 .

23. Pasteur, M. C. et al., (2000) as seen in: Wickremasinghe, M., Ozerovitch, L. J., Davies, G. (2005). Non-tuberculosis Mycobacteria in Patients with Bronchiectasis. Thorax, 2005; 60:1045-1051. 